\title{
Hypercalcemia of Malignancy: Clinical Characteristics and Treatment Outcome
}

\author{
Indra Wijaya, Amaylia Oehadian, Rachmat Sumantri \\ Division of Hematology and Medical Oncology Universitas Padjadjaran \\ Dr. Hasan Sadikin General Hospital
}

\begin{abstract}
Hypercalcemia is one of the most common paraneoplastic syndromes in hospitalized malignancy patients. The aim of this study was to determine the clinical characteristics and treatment outcome in hypercalcemia of malignancy. This was a study using medical records of patients with malignancy hospitalized in the Departement of Internal Medicine, Dr. Hasan Sadikin Hospital Bandung between December 2008 and March 2011. Statistical analysis was performed by Wilcoxon and Mann-Whitney tests. There were 40 patients with hypercalcemia of malignancy, consisted of 22 hematologic malignancies and 18 solid tumors. Disturbance of consiousness were found in 4, dehydration in 18, constipation in 6 , and nausea and vomiting in 6 subjects. In 16 subjects, no symptoms were found. All subjects received rehydration with normal saline. Bisphosphonate was given in 26 subjects. The difference of decreasing ion calcium level, between the groups who were treated with or without bisphosphonate was $0.59(0.01-1.17) \mathrm{mg} / \mathrm{dL}, \mathrm{p}=0.0001$. In conclusion, hematologic and solid tumors are found in about the same proportion in hypercalcemia associated malignancy. Treatment either with or without bisphosphonate shows good results. [MKB. 2014;46(2):111-17]
\end{abstract}

Key words: Bisphosphonate, hypercalcemia of malignancy, rehydration

\section{Hiperkalsemia pada Keganasan: Karakteristik Klinik dan Luaran Terapi}

\begin{abstract}
Abstrak
Hiperkalsemia merupakan salah satu sindrom paraneoplasma yang sering ditemukan pada pasien keganasan. Tujuan penelitianiniuntukmengetahuikarakteristik klinis dan respons terapipenderita denganhiperkalsemia padakeganasan. Penelitian ini menggunakan data rekam medis pasien yang dirawat di Departemen Penyakit Dalam Rumah Sakit Dr. Hasan Sadikin Bandung periode Desember 2008-Maret 2011. Analisis statistik menggunakan Uji Wilcoxon. Dari 40 penderita dengan hiperkalsemia pada keganasan, didapatkan 22 keganasan hematologi dan 18 tumor padat. Gejala klinis yang ditemukan adalah gangguan kesadaran pada 4 subjek, dehidrasi pada 18 subjek, konstipasi pada 6 subjek, mual dan muntah pada 6 subjek. Pada 16 subjek tidak ditemukan gejala. Semua subjek mendapatkan rehidrasi dengan $\mathrm{NaCl} 0,9 \%$. Dua puluh enam subjek mendapat terapi bisfosfonat. Perbedaan penurunan kadar kalsium ion antara kelompok yang mendapatkan bisfosfonat dan tidak adalah $0,59(0,01-1,17) \mathrm{mg} / \mathrm{dL}, \mathrm{p}=0,0001$. Simpulan, proporsi keganasan penyebab hiperkalsemia hampir sama antara keganasan hematologi dan tumor padat. Terapi rehidrasi dengan $\mathrm{NaCl} \mathrm{0,9 \%} \mathrm{tanpa} \mathrm{atau} \mathrm{disertai} \mathrm{bisfosfonat} \mathrm{memberikan} \mathrm{hasil} \mathrm{yang} \mathrm{baik.} \mathrm{[MKB.} \mathrm{2014;46(2):111-17]}$
\end{abstract}

Kata kunci: Bisfosfonat, hiperkalsemia pada keganasan, rehidrasi

Correspondence: Indra Wijaya, dr., Sp.PD, Division of Hematology and Medical Oncology Universitas Padjadjaran/Dr. Hasan Sadikin Hospital, Pasteur 38, Bandung 40161, mobile 08122013739, e-mail indrawijayaipd@gmail.com 


\section{Introduction}

Malignancy adversely affects the bone as well as mineral metabolism through a broad spectrum of mechanisms. While focal osteolysis in metastasis sites is the most common skeletal manifestation of cancer, systemic effects such as hypercalcaemia or diffuse osteopenia are also common. Neoplasma can alter calcium homeostasis indirectly through the production of endocrine factors resulting in humoral hypercalcemia of malignancy. The mechanisms that are thought to be important during the development of hypercalcemia include bone-resorbing cytokines; parathyroid hormonerelated peptide secreted by the tumor that binds to parathyroid hormone receptors; tumor-mediated calcitriol production; and, occasionally, ectopic parathyroid hormone secretion..$^{1-3}$

Malignancy is one of the most common causes of hypercalcemia in hospitalized patients. In addition, hypercalcemia is one of the more common paraneoplastic syndromes. ${ }^{1}$ In overall, hypercalcemia of malignancy (HCM) occurs in $10-20 \%$ of all patients with malignancy. As a paraneoplastic syndrome, HCM is commonly seen in association with multiple myeloma (MM) and breast, lung, renal and ovarian neoplasms. Hypercalcemia complicates $20-40 \%$ of cases of MM. $^{3}$

The management of patients with HCM depends on the severity of symptoms and the degree of hypercalcemia. ${ }^{3}$ Even though control of hypercalcemia is usually successful, the presence of this complication is associated with a poor prognosis. ${ }^{1}$ Important therapeutic modalities include the following modalities: oral phosphates, saline hydration, gallium nitrate, calcitonin, corticosteroids, bisphosphonates, and dialysis. ${ }^{3,4}$

Currently, there is no study on the clinical characteristics and treatment of hypercalcemia of malignancy in Dr. Hasan Sadikin Hospital Bandung. The aim of this study was to obtain information about the clinical characteristics and treatment outcome in hypercalcemia of malignancy. This study results could be used to improve recognition and management of the hypercalcemia of malignancy.

\section{Methods}

This is a study using medical record of patients with malignancy who were hospitalized at the Departement of Internal Medicine, Dr. Hasan Sadikin Hospital Bandung during the period of December 2008-March 2011. Inclusion criteria were age above 14 years old, had hematologic malignancy or solid tumor confirmed through histopathologic analysis. Patients with acute or chronic renal failure, granulomatous disorders, adrenal insuffuciency, and thyrotoxicosis as well as those with thiazides consumption were not eligible for this study.

The data was presented as frequency and median. The ionized calcium level before and 1 day after bisphosphonate treatment was analyzed. The difference between ion calcium level before and after treatment was calculated by Wilcoxon test. The difference in the changes of ion calcium between subjects treated with biophosphonate and those who did not receive bisphosphonate was calculated by Mann-Whitney test.

\section{Results}

There were 40 subjects with hypercalcemia of malignancy, consisted of 22 with hematologic malignancies and 18 with solid tumors. Among subjects with hematologic malignancies, 15 were found with malignant lymphoma, followed by seven subjects with myeloma multiple. Among all solid tumors, most were found in the breast, followed by lung, head and neck cancer, i.e., 7, 5 and 3 respectively. Prostate, pancreas and renal cell carcinomas were found in 1 subject for each cancer type.

The changes in ion calcium level before and after treatment were available in 29 subjects (Table 3). The difference in the decreasing ion calcium level between the group who received bisphosphonate and not was 0.59 (0.01-1.17) $\mathrm{mg} / \mathrm{dL}, \mathrm{p}=0.0001$.

Elevation of ion calcium level in our study subjects was mild in 14 , moderate in 4 , severe in 11, and life threatening in 11 subjects. Among 11 subjects with life threatening HCM, no symptom was found in 4, dehydration was found in 3, loss of consciousness in 2 and constipation in 1 subject. There was no cardiac arrest in all our subjects. Among 16 subjects without symptoms, we found mild, severe and life threatening HCM in 8,4 and 4 subjects, respectively.

\section{Discussion}

Among all causes of hypercalcemia, primary hyperparathyroidism and malignancy are the most common, accounting for more than $90 \%$ of cases. ${ }^{4}$ Hypercalcemia has been reported to occur in up to $20-30 \%$ of patients with cancer at some time during the course of their disease. Hypercalcemia leads to a progressive mental impairment, which include coma, as well as renal failure. In patients with cancer, these complications are particularly 
Indra Wijaya: Hypercalcemia of Malignancy: Clinical Characteristic and Treatment Outcome

Table 1 Subjects Characteristics

\begin{tabular}{|c|c|}
\hline Characteristics & \\
\hline \multicolumn{2}{|l|}{ Age (years) } \\
\hline Median & 55.5 \\
\hline Range & $14-74$ \\
\hline \multicolumn{2}{|l|}{ Sex } \\
\hline Male & 21 \\
\hline Female & 19 \\
\hline \multicolumn{2}{|l|}{ Malignancy } \\
\hline Hematologic & 22 \\
\hline Solid tumor & 18 \\
\hline \multicolumn{2}{|l|}{ Ion Calcium level (mg/dL) } \\
\hline On admission (mg/dL) & $6.9(5.39-10.48)$ \\
\hline After treatment $(\mathrm{mg} / \mathrm{dL})$ & $5.73(4.39-8.37)^{*}$ \\
\hline \multicolumn{2}{|l|}{ Severity of HCM } \\
\hline Mild (>6 mg/dL) & 14 \\
\hline Moderate $(>6.4 \mathrm{mg} / \mathrm{dL})$ & 4 \\
\hline Severe $(>6.8 \mathrm{mg} / \mathrm{dL})$ & 11 \\
\hline $\begin{array}{l}\text { Life threatening }(>7.4 \\
\mathrm{mg} / \mathrm{dL})\end{array}$ & 11 \\
\hline \multicolumn{2}{|l|}{ Treatment } \\
\hline Bisphosphonates & 26 \\
\hline No bisphosphonates & 14 \\
\hline \multicolumn{2}{|l|}{ Bone metastase } \\
\hline Yes & 19 \\
\hline No & 21 \\
\hline \multicolumn{2}{|l|}{ Renal impairment } \\
\hline Yes & 21 \\
\hline No & 19 \\
\hline \multicolumn{2}{|l|}{ Chemotherapy } \\
\hline Yes & 15 \\
\hline No & 25 \\
\hline
\end{tabular}

*only available in 29 subjects, HCM: hypercalcemia of malignancy

common terminal events. The detection of hypercalcemia in patients with cancer signifies a very poor prognosis with approximately $50 \%$ of such patients die within 30 days. ${ }^{5}$ Hypercalcemia associated with cancer can be clasified into four types (Table 4).

In our study, there were 40 subjects with hypercalcemia of malignancy (HCM), consisted of $22(55 \%)$ hematologic malignancies and 18 $(45 \%)$ solid tumors. Among the hematologic malignancy, malignant lymphoma was found in fifteen subjects, followed by seven subjects with
Table 2 Clinical Manifestation of Hypercalcemia

\begin{tabular}{lc}
\hline Clinical Manifestations & n \\
\hline No symptom & 16 \\
$\begin{array}{l}\text { Disturbance of } \\
\text { consiousness }\end{array}$ & 4 \\
Dehydration & 18 \\
Constipation & 6 \\
Nausea and vomiting & 6 \\
\hline
\end{tabular}

myeloma multiple. Our result was about the same as the previous report. ${ }^{3}$ Among patients with skeletal involvement, HCM is most common in patients with multiple myeloma, affecting 30\% to more than $80 \%$ of these patients. ${ }^{7}$ It is the most common cause of hypercalcemia in the inpatient setting. It occurs in patients with both solid tumors and hematologic malignancies. The most common cancers associated with hypercalcemia are breast and lung cancer and multiple myeloma. ${ }^{8,9}$

Among 18 subjects with solid tumor, the most frequent was breast cancer, followed by lung, head and neck in 7,5 and 3 subjects respectively. Prostate, pancreas and renal cell carcinomas were found in one subject for each cancer type. Hypercalcemia of malignancy is rare in patients with prostate cancer. ${ }^{7}$ Our study only found 1 prostate cancer subject with HCM.

Patients with HCM may present with wide range of symptoms, but the development and severity of symptoms do not appear to be strictly correlated with the serum calcium levels. The rapidity of onset is more likely to correlate with the symptom severity rather than the degree of hypercalcemia. ${ }^{10}$

The early symptoms of HCM are mild and can be difficult to distinguish from those of underlying disease or the side effects of cancer therapy. Recognition of the early symptoms of HCM is vital because, if left untreated, it can progress rapidly and may become severe of life threatening. Progression of HCM can be prevented with apropriate measures, including hydration, anticancer therapy, and treatment with bisphosphonates. ${ }^{7,11,12}$

Hypercalcemia is, in almost all patients, due to an elevation in the physiologically important ionized (or free) calcium concentration. However, $40-45 \%$ of the calcium in serum is bound to protein, principally albumin. ${ }^{13}$

Elevation of ion calcium level in our study subjects were mild in 14 , moderate in 4 , severe in 11 and life threatening in 11 subjects. Among eleven subjects with life threatening HCM, no symptom was found in 4 , dehydration in 3 , loss of 
Table 3 Changes of Ion Calcium Level Before and After Treatment

\begin{tabular}{lcccc}
\hline & \multicolumn{2}{c}{ Ion Calcium Level (mg/dL) } & p \\
& Before Treatment & After Treatment & Changes & $0.0001^{*}$ \\
All subjects & 7.31 & 5.7 & 1.43 & $(0.45-3.67)$ \\
Bisphosphonate & $(5.6-10.48)$ & $(4.39-8.33)$ & & $0.0001^{*}$ \\
Treatment & & & 1.68 & \\
Yes & 7.32 & 5.57 & $(0.53-3.67)$ & 1.04 \\
No & $(5.6-10.48)$ & $(4.39-8.37)$ & $(0.45-2.46)$ & \\
\hline
\end{tabular}

*Wilcoxon test; **Mann Whitney test: the difference of decreasing ion calcium level, between the group who received bisphosphonate and not

consciousness in 2 and constipation in 1 subject. There was no cardiac arrest in all our subjects. Among 16 subjects without symptoms, we found mild, severe and life threatening HCM in 8,4 and 4 subjects, respectively. Our results showed wide variety of symptoms and HCM level. These results were consistent with the previous study that reported HCM may present with wide range of symptoms but the development and severity of symptoms do not appear to be strictly correlated with serum calcium levels. ${ }^{7,12}$

Treatment of HCM revolves around these two principles, i.e. treatment of the underlying malignancy along with the reduction of the serum calcium level. ${ }^{6}$ The ultimate treatment of HCM is eradication of the underlying cancer. However, cure is frequently not possible and in patients with symptomatic or life-threatening hypercalcemia, therapy must be aimed specifically againts the mediating mechanisms. The presence of increased osteoclastic bone resorption is seen in essentially every patient with HCM and, therefore, a key target for treatment and prevention of hypercalcemia. Two of these mechanisms in particular, increased osteoclastic bone resorption and increased renal tubular calcium reabsorption, are common to most patients with HCM, even though those cases not associated with parathyroid hormone related peptide (PTHrP) production. Medical therapy is, therefore, aimed at inhibiting bone resorption and promoting renal calcium excretion. ${ }^{1,11}$

Evidence-based therapies for management include intravenous crystalloid fluids with or without loop diuretics, bisphosphonates, calcitonin,

Table 4 Type of Hypercalcemia Associated with Cancer*

\begin{tabular}{lclll}
\hline \multicolumn{1}{c}{ Type } & $\begin{array}{c}\text { Frequency } \\
(\mathbf{\%})\end{array}$ & Bone Metastases & Causal Agent & Typical Tumors \\
\hline $\begin{array}{l}\text { Local osteoltic } \\
\text { hypercalcemia }\end{array}$ & 20 & Common, extensive & $\begin{array}{l}\text { Cytokine, } \\
\text { chemokines, PTHrP }\end{array}$ & $\begin{array}{l}\text { Breast cancer, } \\
\text { multiple myeloma, } \\
\text { lymphoma } \\
\text { Squamous-cell }\end{array}$ \\
$\begin{array}{l}\text { Humoral hypercalcemia } \\
\text { of malignancy }\end{array}$ & 80 & Minimal or absent & PTHrP & $\begin{array}{l}\text { cancer, renal, ovarian, } \\
\text { renal, ovarian, } \\
\text { endometrial, HTLV- } \\
\text { associated lymhoma, } \\
\text { breast cancer }\end{array}$ \\
$\begin{array}{l}1,25(\mathrm{OH}) 2 \mathrm{D}-\text { secreting } \\
\text { lymphoma }\end{array}$ & $<1$ & Variable & Lymphoma (all types) \\
$\begin{array}{l}\text { Ectopic } \\
\text { hyperparathyroidism }\end{array}$ & $<1$ & Variable & $1,25(\mathrm{OH}) 2 \mathrm{D}$ & $\begin{array}{l}\text { Lymariable } \\
\text { Parathyroid }\end{array}$ \\
\hline
\end{tabular}

*PTHrP:parathyroid hormone related peptide; 1,25(OH)2D: 1,25 dihydroxyvitamin D; HTLV: human T-cell lymphotropic virus. 
Table 5 Symptoms and Calcium Serum Concentration (CSC) Level 7

\begin{tabular}{|c|c|c|c|c|}
\hline \multirow[t]{2}{*}{ HCM severity } & $\begin{array}{c}\text { Total } \\
\text { Calcium } \\
\end{array}$ & Bone Metastases & Ca Ion & \multirow[t]{2}{*}{ Symptoms } \\
\hline & $(\mathrm{mmol} / \mathrm{L})$ & $(\mathrm{mg} / \mathrm{dL})$ & (mg/dL) & \\
\hline Mild & $>3.0$ & $>12$ & $>6$ & $\begin{array}{l}\text { Mild anorexia, } \\
\text { nausea, weight } \\
\text { loss, weakness, } \\
\text { constipation, altered } \\
\text { mental status }\end{array}$ \\
\hline Moderate & $>3.2$ & $>12.8$ & $>6.4$ & $\begin{array}{l}\text { Similar to mild } \\
\text { HCM, with renal } \\
\text { insufficiency and } \\
\text { deposition of calcium } \\
\text { in organs and tissues }\end{array}$ \\
\hline Severe & $>3.4$ & $>13.6$ & $>6.8$ & $\begin{array}{l}\text { Severe nausea } \\
\text { and vomiting, } \\
\text { dehydration, renal } \\
\text { insufficiency and } \\
\text { clouding and loss of } \\
\text { consciousness }\end{array}$ \\
\hline Live-threatening & $>3.7$ & $>14.8$ & $>7.4$ & $\begin{array}{l}\text { Coma and cardiac } \\
\text { arrest }\end{array}$ \\
\hline
\end{tabular}

Normal level of calcium: 2.0-2.7 mmol/L, 8.0-10.8 mg/dL. Normal level of calcium ion: 4.7-5.2 mg/dL., HCM: hypercalcemia of malignancy

gallium nitrate and corticosteroids..$^{3,4,6,14,15}$

The important general supportive measures include the removal of calcium from parenteral feeding solutions (a measure often overlooked); the discontinuation of oral calcium supplement in enteral feeding solutions or in the form of calcium tablets; the discontinuation of medications that may independently lead to hypercalcemia (e.g., lithium, calcitriol, vitamin D and thiazides); an increase in the weight-bearing mobility of the patient, if possible; and the discontinuation of the use of sedative drugs, including analgesic drugs if possible to enhance the patient's mental clarity and promote wight-bearing ambulation. ${ }^{5}$

Many hypercalcemia patients are presented with dehydration due to renal water concentrating defects (nephrogenic diabetes insipidus) and decreased oral hydration resulting from anorexia and nausea, vomiting, or both. The dehydration leads to a reduction in the glomerular filtration rate that further reduces the ability of the kidney to excrete the excess serum calcium. First, therefore, parenteral volume expansion should be initiated, with the administration of normal saline. ${ }^{5,11}$ This first step of therapy serves to rehydrate the patient while enhancing calciuresis by increasing the glomerular filtration rate and reducing the fractional reabsorption of calcium and sodium. ${ }^{1,11}$ Although there are no randomized clinical trial to guide this therapy, in general practice normal saline is administered at a rate of 200-500 $\mathrm{mL}$ per hour, depending on the baseline level of dehydration and renal function, the patient's cardiovascular status, the degree of renal impairment, and the severity of the hypercalcemia. These factors must be assessed with the use of careful clinical monitoring for physical finding that are consistent with fluid overload. The goals of treatment are to increase the glomerular filtration rate that will increase the filtered load of calcium which passes through the glomerulus into the tubular lumen and to inhibit calcium reabsorption in the proximal nephron (because saline itself is calciuretic). ${ }^{5}$

The use of loop diuretics, such as furosemide, to enhance calcium excretion is frequently overemphasized in clinical practice. These agents may exacerbate fluid loss; therefore, their use should be limited to the volume-repleted patient and only then with close monitoring of volume status. Hydration alone rarely results in full resolution of hypercalcemia, however and more aggresive therapies are usually needed. ${ }^{1}$

Intravenous bisphosphonates are by far the best studied, the safest and most effective agents for use in patients with hypercalcemia associated with cancer. ${ }^{5}$ Bisphosphonate are currently the mainstay for long-term treatment of 
hypercalcemia and osteolytic bone disease. They have an affinity for bone surfaces undergoing active resorption and are released in the bone microenvirontment during remodelling. ${ }^{1,16}$

Bisphosphonates are potent inhibitors of bone resorption and are the most effective therapy for HCM. Bisphosphonate compounds can be divided into two distinct pharmacological classes with different mechanisms of action depending on whether they contain a nitrogen atom in their side chains of non-nitrogen-containing bisphosphonates, which are the first generation bisphosphonates, that include etidronate and clodronate, are metabolized intracellularly to cytotoxic, non-hydrolyzable analogs of adenosine triphosphate (ATP) that may inhibit ATPdependent intracellular enzymes in osteoclasts. The nitrogen-containing bisphosphonates, which are second or third generation bisphosphonates that include pamidronate, alendronate, and ibandronate, inhibit protein prenylation which leads to loss of membrane localization of small $\mathrm{G}$ proteins such as Ras, Rho and Rac. Consequently, osteoclasts may undergo apoptosis. They are more potent than the first-generation bisphosphonates and have been used for the treatment of $\mathrm{HCM} .{ }^{17}$ Bisphosphonate therapy should be initiated as soon as hypercalcemia is discovered, because a response requires $2-4$ days and the nadir in serum calcium generally occurs within 4-7 days after therapy is initiated. Approximately $60-90 \%$ of patients have normal serum calcium levels within 4-7 days and responses last for 1-3 weeks. ${ }^{5}$ In the United Sates, the two drugs that are approved by the Food and Drug Administration (FDA) and are currently considered the agents of chouce in the treatment of mild-to-severe hypercalcemia that is associated with cancer are pamidronate and zoledronate. Zoledronic acid is superior to pamidronat for the treatment of HCM with $4 \mathrm{mg}$ as the recommended dose im the initial treatment of $\mathrm{HCM}$ and $8 \mathrm{mg}$ for relapsed of refractory HCM. ${ }^{18-20}$

In continental Europe, the United Kingdom and other countries, ibandronate and clodronate are also widely used. ${ }^{5}$ In our study, normal saline hydration was given to all subjects. Twenty six $(65 \%)$ subjects received bisphosphonate. Due to financial problem, all patients could not received zoledronic acid and received clodronic acid instead. We had calcium ion level data before and after treatment in 29 subjects. All subjects had decreased ion calcium level after treatment. The ion calcium level in subjects received bisphosphonate before and after treatment were $7.32(5.6-10.48 \mathrm{mg} / \mathrm{dL})$ and $5.57(4.39-8.37$ $\mathrm{mg} / \mathrm{dL}$ ), respectively. The ion calcium level in subjects who did not received bisphosphonate was $6.88(5.63-8.75 \mathrm{mg} / \mathrm{dL})$ before the treatment and $6.06(4.5-7.7 \mathrm{mg} / \mathrm{dL})$ after the treatment. The difference of decreasing ion calcium level between subjects who received bisphosphonate and nor was $0.59(0.01-1.17) \mathrm{mg} / \mathrm{dL}, \mathrm{p}=0.0001$.

In patients who have cancers that are likely to respond to therapy but in whom acute or chronic renal failure is present, aggressive saline infusion is not possible and other therapies such as bisphosphonates should be used with caution. In these circumstances, dialysis with dialysate containing litle or no calcium is a reasonable and highly effective option for selected patient. ${ }^{5}$ In our study, no patients underwent dialysis. The definite treatment (chemotherapy) was given in 15 subjects.

In conclusion, the malignancy causing hypercalcemia was about the same proportion between hematologic and solid tumor. Among hematologic malignancy, malignant lymphoma followed by myeloma multiple. Among solid tumor, the most frequent one was breast cancer followed by lung cancer and head and neck cancer. Disturbance of consiousness, dehydration, constipation, nausea and vomiting were found. Treatment either with bisphosphonate or normal saline rehydration alone gave good result.

\section{References}

1. Clines GA, Guise TA. Hypercalcemia of malignancy and basic research on mechanisms responsible for osteolytic and osteblastic metastasis to bone. Endocr Relat Cancer. 2005;12(3):549-83.

2. Mundy GR, Edwards JR. PTH-related peptide (PTHrP) in hypercalcemia. J Am Soc Nephrol. 2008;19(4):672-5.

3. Jibrin IM, Lawrence GD, Miller CB. Hypercalcemia of malignancy in hospitalized patients. Hosp Phys. 2006;11:29-35.

4. Carroll MF, Schade DS. A practical approach to hypercalcemia. Am Fam Physician. 2003;67(9):1959-66.

5. Stewart AF. Clinical practice: hypercalcemia associated with cancer. N Engl J Med. 2005; 352(4):373-9.

6. McMahan J, Linneman T. A case of resistant hypercalcemia of malignancy with a proposed treatment algorithm. Ann Pharmacother. 2009;43(9):1532-8.

7. Loftus LS, Edwards-Bennett S, Sokol GH. Systemic therapy for bone metastases. Cancer Control. 2012;19(2):145-53.

8. Clines GA. Mechanism and treatment of hypercalcemia of malignancy. Curr Opin Endocrinol Diabetes Obes. 2011;18(6):339- 
46.

9. Higdon ML, Higdon JA. Treatment of oncologic emergencies. Am Fam Physician. 2006;74(11):1873-80.

10. 10. Seccareccia D. Cancer-related hypercalcemia. Can Fam Physician. 2010; 56(3):244-6.

11. Makras P, Papapoulos SE. Medical treatment of hypercalcaemia. Hormones. 2009;8(2):8395.

12. Lewis MA, Hendrickson AW, Moynihan TJ. Oncologic emergencies: pathophysiology, presentation, diagnosis and treatment. CA Cancer J Clin. 2011;61(5):287-314.

13. Pelosof LC, Gerber DE. Paraneoplastic syndromes: an approach to diagnosis and treatment. Mayo Clin Proc. 2010;85(9):83854.

14. LeGrand SB, Leskuski D, Zama I. Narrative review: furosemide for hypercalcemia: an unproven yet common practice. Ann Intern Med. 2008;149(4):259-63.

15. Assadi F. Hypercalcemia: an evidence-based approach to clinical cases. Iran J Kidney Dis. 2009;3(2):71-9.

16. Drake MT, Clarke BL, Khosla S. Bisphoshonates: mechanism of action and role in clinical practice. Mayo Clin Proc. 2008;83(9):1032-45.

17. Kawada K, Minami H, Okabe K, Watanabe T, Inoue K, Sawamura M, et al. A multicenter and open label clinical trial of zoledronic acid $4 \mathrm{mg}$ in patients with hypercalcemia of malignancy. Jpn J Clin Oncol. 2005;35(1): 28-33.

18. Polascik TJ. Bisphosphonates in oncology: evidence for the prevention of skeletal events in patients with bone metastases. Drug Des Devel Ther. 2009;3:27-40.

19. Berenson G, Hirschberg R. Safety and convenience of a 15-minute infusion of zoledronic acid. Oncologist. 2004;9(3):31929.

20. Coleman RE. Bispohphonates: clinical experience. Oncologist. 2004;9(Suppl 4):1427. 